\title{
REGIONAL COMPETITIVENESS RESPONSE TO INNOVATION CHANGES: ISSUES OF EVALUATION
}

\author{
Aleksandra POLYAKOVA ${ }^{1,2}$, Vladimir KOLMAKOV ${ }^{1}$, Olga YAMOVA ${ }^{2}$ \\ ${ }^{1}$ Plekhanov Russian University of Economics, Moscow, Russia \\ ${ }^{2}$ Industrial University of Tyumen, Tyumen, Russia
}

\begin{abstract}
Our research addresses regional competitiveness as the function of innovation activity. We use 15 indicators to cluster the Russian regions in five different groups, and to propose and to estimate the composite competitiveness quotient of a region in order to further regress it by innovation activity indicators. We prove that different groups of regions - "potential competitiveness leaders", "traditional competitiveness factor employers", "competitiveness outsiders", "moderate competitiveness regions", "competitiveness leaders" - are prone to respond to innovation parameters change in a different manner, thus uniform regulation and strategies are irrelevant. We contribute to the methodology of regional competitiveness estimation by presenting a ready-to-deploy set of data structures and model propositions. Our measure of competitiveness is economy related and easily adjustable regarding the specific innovation phenomena that influence the corporate and aggregate performance, value or efficiency of regions.
\end{abstract}

Key Words: regional competitiveness, innovation, change, value.

\section{Introduction}

Competitiveness is a multidimensional characteristic of the quality of a region's socioeconomic space. It determines the efficiency of regional resources' use and it is reflected by the improvement of the quality of life in a region. Innovation is often considered as a driver of competitiveness, or at least as a significant contributor to it. Innovation patterns change both gradually and drastically, yet they always depend on the global phenomena that drive the change. Further way down to regions or enterprises, the propagation of innovation impact depends on the object-specific features such as innovation receptivity and preparedness, on the one hand, and resistance to change, on the other hand.

Economic competitiveness is a complex phenomenon that is addressed to on different levels, including national and regional levels. The problem of intranational competitiveness is relevant to federations with a multitude of entities - regions that are often characterized by significant differentiation and asymmetry determined both by natural, historical and cultural, and synthetic factors. The existing factor differences make uniform policies inappropriate to address the issues of a given region thus diluting resources and, quite often, further fertilizing the asymmetry. Still, the general path of innovation can be considered fruitful for every region, but the content and drive of innovation need to be different, which means it must be identified and measured.

Methodology advances in measuring competitiveness fall out of the scope of our research. Quite sure, another attempt to propose a new metric for any level of competitiveness will highly likely replicate an existing approach or clarify it by eliminating its critical drawbacks. Furthermore, many authors are focused on the issue of competitiveness assessment using complex indicators, while instruments to enhance it are the matter of a much moderate discussion. We introduce an instrumental way to get an informative measure of competitiveness with a higher extent of explanatory power. To do that, we employ an integral 
indicator approach preceded by the objects' multidimensional classification.

Estimates of regional competitiveness, both statically and dynamically, are extremely important since they provide a key to proper comparisons with the other regions' relevant indicators and they offer a distinct measure of the possible mismatch between the current strategies of social and economic development and the obvious trends in the development: it allows to revise either the objective or means of its achievement. Another important use of the regional competitiveness estimates is represented by measuring the general performance of a regional authority since its primary objective is to maintain the balanced development of a territory that would result in the increase of efficiency and quality of life promotion. Given the latter, at least two directions of research are actual. The first one is the traditional look-up of factors that determine the competitiveness of a region today and in a strategic perspective. The second direction is the development of mechanisms for the manageable and predictable influence on those factors to enable the growth of competitiveness.

We seek to prove the following research hypothesis: the Russian regions, given the existing level of differentiation and asymmetry, benefit from innovation differently in terms of their competitiveness as an integral characteristic of their relative performance and development. The different receptivity to innovation undermines any uniform policy and strategy that could be applied and it requires custom development models that provide the maximization of value return on the investment in innovation and the quality-of-life return on the investment in innovation. Therefore, we structured the research in the following manner:

1. We assumed that the 80 Russian regions had been significantly different, but not to the extent that would require 80 specific models - there had been a certain extent of homogeneity that allowed to derive a distinct typology and apply analytical procedures to several groups' averages. To get the groups, we:

1.1. collected the database of various indicators that characterized the regions;

1.2. censored the indicators to exclude multicollinearity and to get a more compact model design;

1.3. applied the k-means clustering technique to get the regions in groups;

1.4. analyzed cluster properties and cross-cluster differences to label them according to their competitiveness level.

2. We introduced the competitiveness quotient and estimated its values for all the regions.

3. We found the quotient average values for regions in each cluster in order to assign the dependent variable in the model. An analysis of the quotient dynamics explained the model type choice.

4. Using the official statistics, we decomposed "innovation" in measurable factors in order to include it in a regression model.

5. Having regressed the competitiveness quotient by innovation factors, we concluded on the hypothesis plausibility.

\section{Literature review}

Regions are the primary spatial units of organization that compete to attract investment; thus, the attention has turned to competitiveness at a more regional level (Huggins et al. 2016). Competitiveness is a multidimensional and complex category that characterizes a market economy. Regional competitiveness acts as an independent theoretical category described in different studies.

Porter $(1998,2003)$ plays a significant role in studying competitiveness of territories. His key concept is the thesis that the most important competitive advantages in the global economy often depend on the cluster's location (Porter 1998). So, according to Porter (2003: 571), "many of the essential determinants of economic performance appear to reside in regions", 
thus regional competitiveness is represented by the productivity with which a region uses its resources - "the productivity of all the clusters in which the region has a meaningful position" (Porter 2003: 568). Further developments and linkages of regional competitiveness with the related concept of cluster are present in Pessoa (2013) whose contribution was to reframe the regional to spatial competitiveness emphasizing the gap between theory and policy implementation in managing regional competitiveness beyond Porter's (2003) approach to identify clusters as competitiveness drivers. Approximately the same attitude is found in Fundeanu and Badele (2014: 405) who prove that "innovative clusters are most likely to provide a new type of economy based on innovation, by means of producing dense knowledge flows for strengthening entrepreneurship by stimulating the formation of new businesses, thereby influencing the regional economic performance". Still, the cluster approach to regional competitiveness management is often used in a widely criticized manner: top-down cluster identification prevails over the bottom-up approach.

The attempts to define regional competitiveness vary significantly, but the researchers are unanimous in factor-based representation. They treat competitiveness as a specific combination of institutional factors (Krueger et al. 2018) or having the potential to ensure a high standard of living and quality of life in a region, according to national and global standards (Prokop and Stejskal 2015). Thus, one tier of studies considers competitiveness as a set of advantages used to maximize certain economic indicators and it interprets it as the ability of a region to discover, create and employ competitive advantages in comparison with other regions. This is the competitiveness phenomenon that it is currently used to explain the determinants of uneven development across regions, as supported, e.g., by Gavurova et al. (2017) or Huggins and Thompson (2017). In line with the latter, Roșu and Dona (2016: 445) define macroeconomic-level competitiveness as "the obtained results, materialized into labour employment and income levels, as well as the factors that determine them".

Compared to the EU, the Russian legislation has no regulations on the formal definition of competitiveness or any uniform methodology of measuring regional competitiveness like $\mathrm{RCl}$ in Europe. In the Russian scientific discourse, regional competitiveness is considered as the ability for sustainable socioeconomic development based on the productive use of resources and with regard to the long-term development objectives. Beyond that generalization, the following aspects of the Russian research of regional competitiveness are notable:

- the relative performance of a region's resources employment (Polyakova et al. 2018);

- the combination of region-specific conditions and factors of production, regarding the aggregate competitiveness of enterprises located and functioning in a region (Kolmakov et al. 2018);

- a region's ability to achieve and maintain high quality of life in line with the national and global standards by developing the new resource potential that outperforms the other regions and generates long-term and resilient competitive advantages (Chaynikova 2010).

- Golovikhin and Nezhivenko (2012) argue that the many attempts to define regional competitiveness are bound to the artificial or mechanistic adaptation of the concept to the specific research or policy task without proper analysis or critique. Yet, they agree that regional competitiveness represents the formalized measure of "one region being better than another" as well as the ability of a region to outperform another one in the foreseen future by employing the competitive advantage.

Summarizing the former and the latter, we strive to follow the definition of Žitek and Klímová (2015): regional competitiveness is a multidimensional characteristic of the socioeconomic space's quality, that determines the productivity of using territorial resources and it is reflected by a higher quality of life in the region. Leading competitive positions require relevant strategies, based on the efficient use of the productive and resource potential to build competitive advantages, to be developed and adapted. Considering the modernization tasks in 
the economy, the implementation of such strategies is reasonable as part of the spatial approach that is widely implemented in European convergence/divergence studies with respect to competitiveness and growth. According to Alexa et al. (2019), the relationship between the regional competitiveness index and growth becomes highly significant when spatial interdependence is accounted for. Given that, we can conclude on the existence of the "growth - innovation - competitiveness" triad with a proven pairwise strong correlation.

The search for the sources and drivers that create competitive advantages plays a leading role in regional competitiveness. Competitive advantages should be considered as a set of conditions in a region that facilitate social and economic development and explain the differences from other regions. The following classification of competitive advantages is seen as the most rational: factor, organizational, strategic and innovation advantages (Zhai and Zhang 2012).

Innovation, as a factor of competitiveness, is critical at all levels of competitive relationships. One of the fundamental areas of regional economic development is the active use and development of regional scientific and technological potential that can ensure stable competitive advantages for specific regions. Innovation's impact on economic systems' competitiveness has been in scope of academic research since the early introduction of Porter's $(1998,2003)$ five forces framework. The contemporary research makes an emphasis on technological and ecological innovation to influence growth and development. The former can be found in Polyakova et al. (2019), and the latter in Ratten (2018), both considering the practical implication of the strategic level of innovation to the management of competitiveness. According to Huggins et al. (2014: 241), "each region has hugely increased its competitiveness through improvements in the capacity to absorb and diffuse knowledge". The assessment of research and development impact and the relations between R\&D, innovations and competitiveness are present in Tiguint and Hossari (2018). However, the innovation receptivity of regions is presumably different due to the specific features of territories and their competitive specialization identified and measured in our recent paper (Kolmakov et al. 2019). On the other hand, innovation change may have different scenarios and be driven by different forces. In addition to technological modernization and product innovations that are widely discussed in the literature, we notice the brand-new phenomena of business-processes' redesign or assets employment mode changes associated with the sharing economy. This is why we address the issues of regional competitiveness sensitivity to changes in parameters of regional innovation activity.

\section{Methodology}

\section{Classification of regions}

Our hypothesis required to derive several notably different groups of regions that would be significantly homogenous within a group. Cluster analysis was found to be the proper solution for the task (Gavurova et al. 2017), given we needed to get a multidimensional and time-steady classification of regions.

The set of indicators to use in clustering was obtained through the two-step procedure. The first step was to use the content analysis of publications that dealt with competitiveness estimations and to get a wide list of indicators after the simple availability check. Žítek and Klímová (2015) used a composite index of 14 partial indicators divided into three groups - input factors, output factors and outcome factors. Alternatively, Yan et al. (2015: 153) provide "a new competitiveness evaluation index system (...) that measures comprehensive capacity, industrial output capacity, research capacity and environmental protection capacity". Huggins et al. (2014) present a rationale and method for quantifying the global competitiveness of regions. 
In numerous Russian and foreign papers, we found evidence of using 42 indicators for the purpose of measuring competitiveness (excluding the ones that were not published by the Russian Statistics Authority). All indicators represented different aspects of regional development (Table 1).

The extended set of indicators for the typology of Russian regions ${ }^{1)}$

Table 1

\begin{tabular}{|c|c|c|c|}
\hline & Indicator & Item & Indicator \\
\hline 1 & Quantity of higher education institutions (units) & 22 & Total imports (millions of US dollars) \\
\hline 2 & $\begin{array}{l}\text { Number of higher education graduates } \\
\text { (thousands of people) }\end{array}$ & 23 & Population (thousands of people) \\
\hline 3 & $\begin{array}{l}\text { Length of railways per } 1000 \text { square } \mathrm{km} \text { of } \\
\text { territory }(\mathrm{km})\end{array}$ & 24 & Sickness cases per 100000 people \\
\hline 4 & Density of roads per $1000 \mathrm{~km}$ of territory $(\mathrm{km})$ & 25 & Crimes per 100000 people \\
\hline 5 & Value of fixed assets (millions of rubles) & 26 & $\begin{array}{l}\text { Visits to theaters (thousands of } \\
\text { people) }\end{array}$ \\
\hline 6 & Depreciation of fixed assets (\%) & 27 & $\begin{array}{l}\text { Annual average employment (thousands } \\
\text { of people) }\end{array}$ \\
\hline 7 & $\begin{array}{l}\text { Foreign capital enterprises' turnover (billions of } \\
\text { rubles) }\end{array}$ & 28 & Registered unemployment level (\%) \\
\hline 8 & Industrial output index & 29 & $\begin{array}{l}\text { Average employment by foreign capital } \\
\text { enterprises (thousands of people) }\end{array}$ \\
\hline 9 & Agricultural output index & 30 & $\begin{array}{l}\text { Air pollution (thousands of tons of } \\
\text { exhaust) }\end{array}$ \\
\hline 10 & Electricity generation (billions of kWh) & 31 & $\begin{array}{l}\text { Number of newly registered } \\
\text { enterprises }\end{array}$ \\
\hline$\overline{11}$ & Value of construction works (millions of rubles) & 32 & $\begin{array}{l}\text { Number of newly registered } \\
\text { enterprises with foreign capital }\end{array}$ \\
\hline 12 & Retail turnover (millions of rubles) & 33 & $\begin{array}{l}\text { Number of PCs per } 100 \text { employed } \\
\text { people }\end{array}$ \\
\hline$\overline{13}$ & Consolidated budget revenue (millions of rubles) & 34 & $\begin{array}{l}\text { Number of technology export } \\
\text { contracts }\end{array}$ \\
\hline$\overline{14}$ & Proportion of loss-bearing enterprises (\%) & 35 & $\begin{array}{l}\text { Number of technology import } \\
\text { contracts }\end{array}$ \\
\hline 15 & Gross regional product per capita (rubles) & 36 & $\begin{array}{l}\text { Value of technologies exported } \\
\text { (thousands of US dollars) }\end{array}$ \\
\hline 16 & Fixed capital investment (millions of rubles) & 37 & $\begin{array}{l}\text { Value of technologies imported } \\
\text { (thousands of US dollars) }\end{array}$ \\
\hline 17 & Fixed capital investment per capita (rubles) & 38 & Number of technologies in use \\
\hline 18 & $\begin{array}{l}\text { Fixed capital investment per enterprise } \\
\text { (thousands of rubles) }\end{array}$ & 39 & $\begin{array}{l}\text { Innovation activity: number of } \\
\text { enterprises implementing innovation as a } \\
\text { percentage to total number of enterprises }\end{array}$ \\
\hline 19 & $\begin{array}{l}\text { Foreign investment inflow (thousands of US dol- } \\
\text { lars) }\end{array}$ & 40 & $\begin{array}{l}\text { Technology innovation expenditure } \\
\text { (millions of rubles) }\end{array}$ \\
\hline 20 & Consumer price index & 41 & $\begin{array}{l}\text { Innovation goods and services } \\
\text { output (millions of rubles) }\end{array}$ \\
\hline 21 & Total exports (millions of US dollars) & 42 & $\begin{array}{l}\text { Innovation products share in the total } \\
\text { output (\%) }\end{array}$ \\
\hline
\end{tabular}

On the second step, all indicators' data were standardized and checked for multicollinearity to exclude the irrelevant and highly correlated ones. After censoring, the residual set contained 15

1) The data were sourced from the Russian Federal Statistics Repository; the time interval was 2007-2017 (the latest available) in order to maintain comparability. 
uncorrelated indicators that were used to classify the total of 80 Russian regions. We used the k-means clustering algorithm to test the outcomes of different clusters and to finally get the set of five groups significantly different from each other. Refer to Fig. 1 for the cluster averages across each of the 15 indicators, as well as the explication of the remaining indicators.

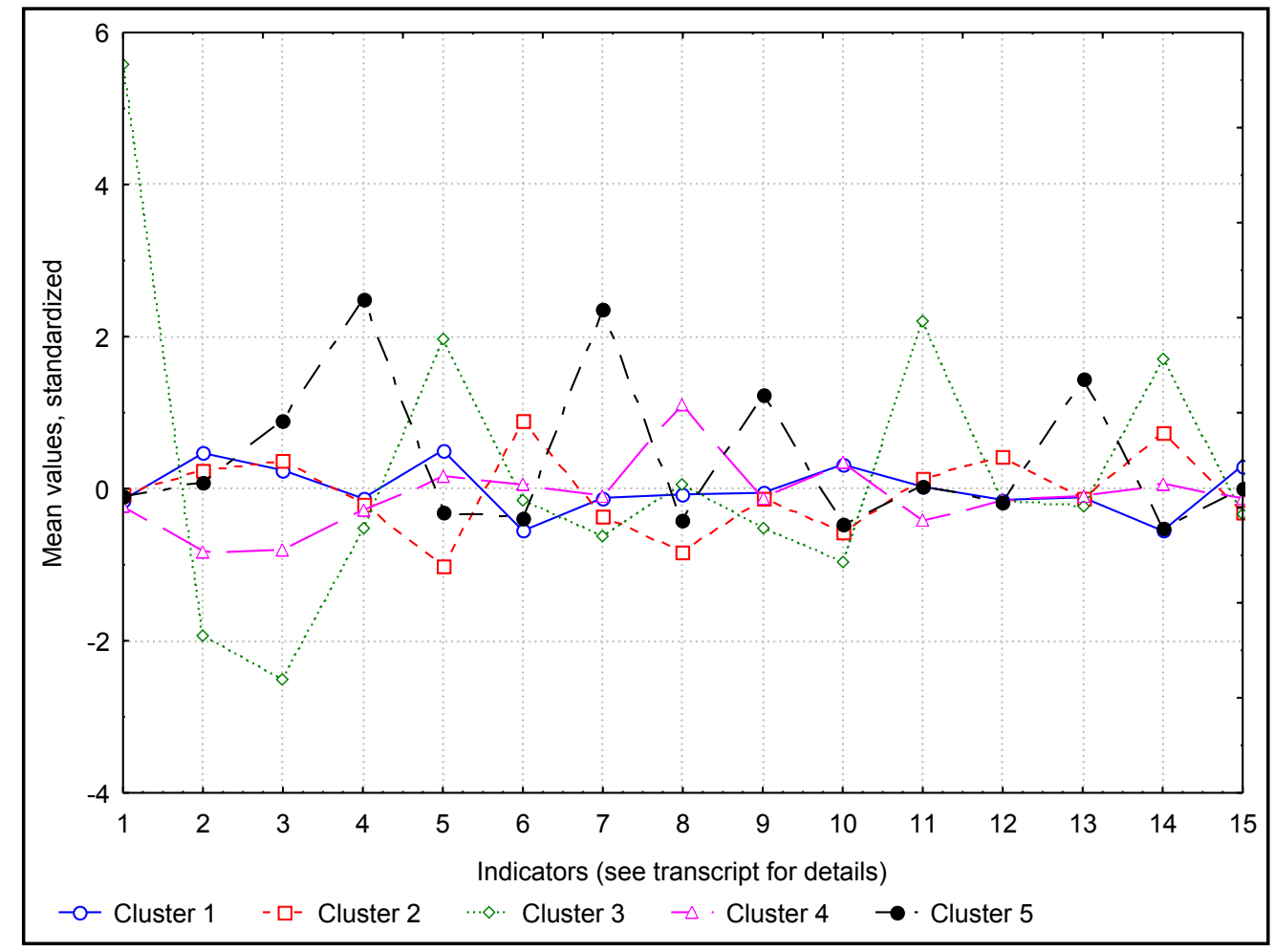

1. Registered unemployment; 2. Sickness per 100000 people; 3. Crimes per 100000 people; 4. Air pollution; 5. Depreciation of fixed assets; 6 . Industrial output index; 7 . Electricity generation; 8 . Length of railways per 1000 square $\mathrm{km}$ of territory; 9. Technology innovation expenditure; 10. Innovation products share in the total output; 11. Proportion of loss-bearing enterprises; 12. Fixed capital investment per capita; 13. Foreign investment inflow; 14. Consumer price index; 15 . Number of technology export contracts.

\section{Fig. 1 - Cluster average values}

In several cases, the cross-cluster differences were not obvious which required to get the intracluster indicators' relative ranking (Table 2).

The cluster differences require several comments. We see that Cluster 3 can be characterized as the "competitiveness outsider". It contains only two regions that were the "troublemakers" in the 90s: Ingush Republic and Chechen Republic, which were the territories of the active warfare until 2003 and counter-terrorist operations until much later periods. It is not necessarily the development problem of the fact that the two regions have the worst values, as it might also be the drawback of statistic data collection that was obviously handicapped. But still, the financial and economic indicators are the worst of all; the best values in the social and ecological spheres can be argued since the minimum air pollution can be the evidence of 


\section{Standardized values of indicators across clusters}

\begin{tabular}{|c|c|c|c|c|c|}
\hline Indicator (driver of competitiveness) & $\begin{array}{c}\text { Cluster } \\
1\end{array}$ & $\begin{array}{c}\text { Cluster } \\
2\end{array}$ & $\begin{array}{c}\text { Cluster } \\
3\end{array}$ & $\begin{array}{c}\text { Cluster } \\
4\end{array}$ & $\begin{array}{c}\text { Cluster } \\
5\end{array}$ \\
\hline $\begin{array}{l}\text { Registered unemployment (lower rates mean labor } \\
\text { market efficiency and attractiveness for quality } \\
\text { migration) }\end{array}$ & -0.145 & -0.063 & 5.580 & -0.237 & -0.100 \\
\hline $\begin{array}{l}\text { Sickness per } 100000 \text { people (the lower the value } \\
\text { is, the more efficient the social policy is) }\end{array}$ & 0.469 & 0.248 & -1.938 & -0.818 & 0.080 \\
\hline $\begin{array}{l}\text { Crimes per } 100000 \text { people (the lower the value is, } \\
\text { the more efficient the social policy is) }\end{array}$ & 0.244 & 0.382 & -2.493 & -0.797 & 0.891 \\
\hline $\begin{array}{l}\text { Air pollution (bivariate indicator: a low emission can } \\
\text { indicate a high extent of modernization or the low } \\
\text { extent of industrialization together with a low } \\
\text { performance of economy) }\end{array}$ & -0.126 & -0.209 & -0.507 & -0.282 & 2.492 \\
\hline $\begin{array}{l}\text { Depreciation of fixed assets (the more assets are } \\
\text { worn out, the lower is the competitiveness due to } \\
\text { the lack of technology advantage; also, an indicator } \\
\text { of low investment appeal) }\end{array}$ & 0.506 & -1.011 & 1.970 & 0.169 & -0.299 \\
\hline $\begin{array}{l}\text { Industrial output index (a straightforward indicator of } \\
\text { economic performance directly related to competi- } \\
\text { tiveness) }\end{array}$ & -0.553 & 0.891 & -0.151 & 0.055 & -0.396 \\
\hline $\begin{array}{l}\text { Electricity generation (a straightforward indicator of } \\
\text { economic performance directly related to competi- } \\
\text { tiveness) }\end{array}$ & -0.119 & -0.352 & -0.625 & -0.093 & 2.369 \\
\hline $\begin{array}{l}\text { Length of railways per } 1000 \text { square } \mathrm{km} \text { of territory } \\
\text { (cargo accessibility is the core factor of production } \\
\text { facilities allocation) }\end{array}$ & -0.075 & -0.830 & 0.048 & 1.104 & -0.405 \\
\hline $\begin{array}{l}\text { Technology innovation expenditure (as the function } \\
\text { of "recent success" and indicator of strategic } \\
\text { resilience) }\end{array}$ & -0.053 & -0.115 & -0.504 & -0.121 & 1.247 \\
\hline $\begin{array}{l}\text { Innovation products share in the total output (the } \\
\text { extent of market conjuncture dependency - older } \\
\text { products are more volatile in terms of demand } \\
\text { stability and substitutes pressure) }\end{array}$ & 0.318 & -0.577 & -0.960 & 0.345 & -0.457 \\
\hline $\begin{array}{l}\text { Proportion of loss-bearing enterprises (the state- } \\
\text { ment of economic policy long-term retrospective, } \\
\text { unless in crisis) }\end{array}$ & 0.026 & 0.141 & 2.197 & -0.417 & 0.030 \\
\hline $\begin{array}{l}\text { Fixed capital investment per capita (reflects the } \\
\text { willingness and ability to invest, even though it may } \\
\text { be the indicator of a "resource-doomed" region) }\end{array}$ & -0.146 & 0.423 & -0.161 & -0.148 & -0.179 \\
\hline $\begin{array}{l}\text { Foreign investment inflow (as the function of } \\
\text { transparency and market perspectives) }\end{array}$ & -0.112 & -0.120 & -0.215 & -0.109 & 1.436 \\
\hline $\begin{array}{l}\text { Consumer price index (the relative performance of a } \\
\text { "small" economy in terms of resources reevaluation } \\
\text { under transportation and other expenditures) }\end{array}$ & -0.552 & 0.734 & 1.712 & 0.071 & -0.525 \\
\hline $\begin{array}{l}\text { Number of technology export contracts (the degree } \\
\text { of the "new economy" development) }\end{array}$ & 0.308 & -0.304 & -0.343 & -0.124 & 0.000 \\
\hline \multicolumn{6}{|c|}{ Legend: } \\
\hline Below average & & ove aver & & Maximu & \\
\hline
\end{tabular}




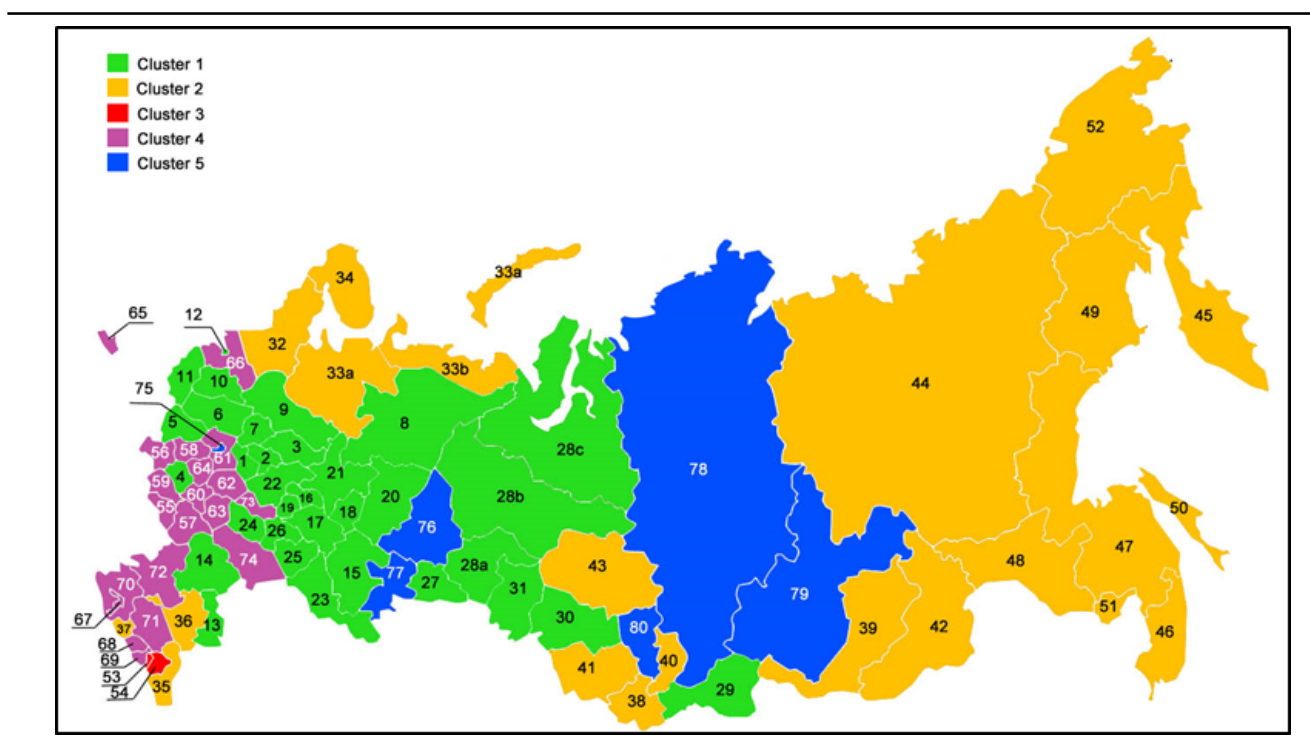

Fig. 2 - Cluster constituents on the administrative map of Russia

Standardized values of indicators across clusters

\begin{tabular}{|c|c|}
\hline Cluster number & Regions (number on the map) \\
\hline $\begin{array}{c}\text { Cluster 1. "Potential } \\
\text { competitiveness } \\
\text { leader" }\end{array}$ & $\begin{array}{l}\text { Vladimir oblast (1), Ivanovo oblast (2), Kostroma oblast (3), Orel oblast (4), Smo- } \\
\text { lensk oblast (5), Tver oblast (6), Yaroslavl oblast (7), Republic of Komi (8), Vologda } \\
\text { oblast (9), Novgorod oblast (10), Pskov oblast (11), city of Saint-Petersburg (12), } \\
\text { Astrakhan oblast (13), Volgograd oblast (14), Republic of Bashkortostan (15), Re- } \\
\text { public of Mari-El (16), Republic of Tatarstan (17), Udmurtia Republic (18), Chuvash } \\
\text { Republic (19), Perm krai (20), Kirov oblast (21), Nizhegorodskaya oblast (22), Oren- } \\
\text { burg oblast (23), Penza oblast (24), Samara oblast (25), Ulyanovsk oblast (26), Kur- } \\
\text { gan oblast (27), Tyumen oblast (28a, includes Khanty-Mansi Autonomous Okrug 28b } \\
\text { and Yamal-Nenets Autonomous okrug 28c), Republic of Tyva (29), Novosibirsk ob- } \\
\text { last (30), Omsk oblast (31) }\end{array}$ \\
\hline $\begin{array}{c}\text { Cluster } 2 . \\
\text { "Traditional factors } \\
\text { employer" }\end{array}$ & $\begin{array}{l}\text { Republic of Karelia (32), Arkhangelsk oblast (33a, includes Nenets Autonomous } \\
\text { okrug 33b), Murmansk oblast (34), Republic of Dagestan (35), Republic of Kalmykia } \\
\text { (36), Karachay-Cherkessia Republic (37), Republic of Altai (38), Republic of Buryatia } \\
\text { (39), Republic of Khakassia (40), Altai krai (41), Transbaikal krai (42), Tomsk oblast } \\
\text { (43), Sakha Republic(44), Kamchatka krai (45), Primorsky krai (46), Khabarovsk krai } \\
\text { (47), Amur oblast (48), Magadan oblast (49), Sakhalin oblast (50), Jewish } \\
\text { autonomous oblast (51), Chukotka autonomous okrug (52) }\end{array}$ \\
\hline Cluster 3. "Outsider" & Ingush Republic (53), Chechen Republic (54) \\
\hline $\begin{array}{l}\text { Cluster 4. "Moderate } \\
\text { competitiveness" }\end{array}$ & $\begin{array}{l}\text { Belgorod oblast (55), Bryansk oblast (56), Voronezh oblast (57), Kaluga oblast (58), } \\
\text { Kursk oblast (59), Lipetsk oblast (60), Moscow oblast (61), Ryazan oblast (62), } \\
\text { Tambov oblast (63), Tula oblast (64), Kaliningrad oblast (65), Leningrad oblast (66), } \\
\text { Republic of Adygea (67), Kabardino-Balkar Republic (68), Republic of north Ossetia } \\
\text { (69), Krasnodar krai (70), Stavropol krai (71), Rostov oblast (72), Republic of } \\
\text { Mordovia (73), Saratov oblast (74) }\end{array}$ \\
\hline $\begin{array}{c}\text { Cluster } 5 . \\
\text { "Competitiveness } \\
\text { leader" }\end{array}$ & $\begin{array}{l}\text { City of Moscow (75), Sverdlovsk oblast (76), Chelyabinsk oblast (77), Krasnoyarsk } \\
\text { krai (78), Irkutsk oblast (79), Kemerovo oblast (80) }\end{array}$ \\
\hline
\end{tabular}


industrial stagnation, lack of manufacture and no energy generation, and the lowest sickness and crime rates might be the consequence of bad statistics or the effect of significant federal investment in the social sphere. Thus, all competitiveness components show the two regions being outsiders. Due to the significant underperformance, this cluster was excluded from further consideration.

The number of regions in clusters is significantly heterogenous: the biggest in number is Cluster 1 (38.75\% of regions), while clusters 2 and 4 contain $26.25 \%$ and $25.0 \%$ respectively. The remaining $10 \%$ regions shape up Cluster $5(7.5 \%$ or 6 regions) and Cluster $3(2.5 \%, 2$ regions, Fig. 2, Table 3).

\section{Competitiveness quotient introduction}

We used the integral quotient approach to competitiveness measurement since it is justified by a vast variety of papers presenting different combinations of composite indices. A comprehensive review of different methods of competitiveness evaluation can be found in Kovalska (2013).

The general expression of the integrated regional competitiveness quotient is the following:

$$
\begin{gathered}
C Q_{i j}=E_{i j} \times I A_{i j} \\
E_{i j}=G R P_{i j} / F A_{i j}
\end{gathered}
$$

where $\mathrm{CQ}$ - competitiveness quotient of region $i$ in year $j$; theoretical $C Q \in[0 ; \infty)$, actual $\mathrm{CQ}_{\mathrm{ij}} \in[0 ; 14.12]$.

$\mathrm{E}$ - output efficiency index of region $i$ in year $j$, theoretical $\mathrm{E} \in[0 ; \infty)$, actual $\mathrm{E}_{\mathrm{i} \in \mathrm{E}} \in[0.11 ; 0.86]$.

$I A$ - innovation activity in region $i$ in year $j$; theoretical $I A \in[0 ; 1]$; actual $I A_{i j} \in[0 ; 0.33]$. See item 39 in Table 1 for explanation, "zero" or not available for regions of Cluster 3 .

GRP - gross regional product of region $i$ in year $j$, rubles.

$\mathrm{FA}$ - total fixed assets in region $i$ in year $j$, rubles

Regarding the regions' distribution by clusters, we can trace the differences between them. Fig. 3 provides the cluster-average values of the regional competitiveness quotient in dynamics. Cluster 3 values are omitted since innovation activity values are zero or missing.

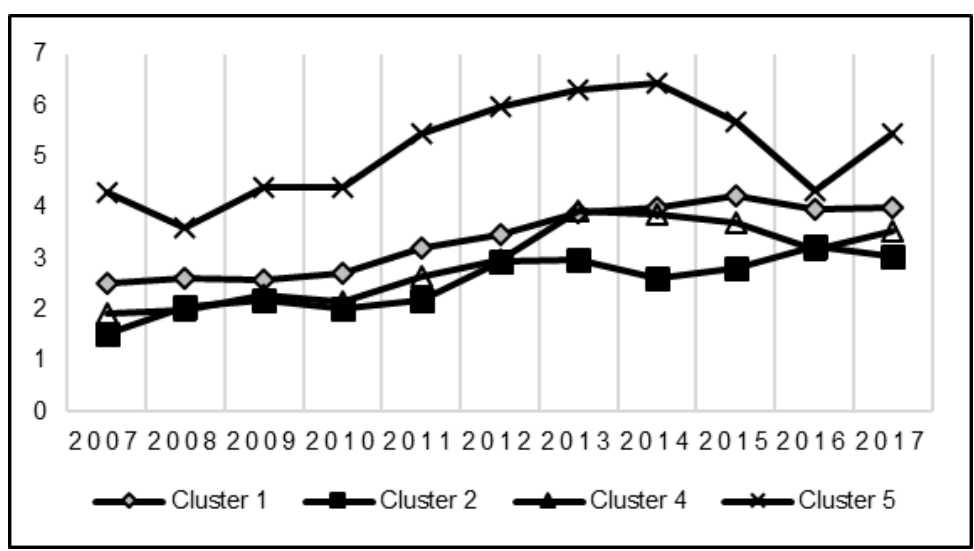

Fig. 3 - Average values of the integrated competitiveness index by clusters 
The visualization enables several verification conclusions on the set of indicators used for the clustering. Thus, clusters 1,2 and 4 fall in approximately the same range of competitiveness quotient values, even though the clusters are quite different from each other. This means that their competitiveness is driven by different factors. Cluster 5 stands out as an outlier compared to all the rest groups.

\section{Regression model design}

Linear regression models, including the lagged ones, allow the comprehensive evaluation of the processes and phenomena causality and their impact-response on power estimates. Regression coefficients are easily interpreted and compared. Our choice of linear regression is based on the "one way causality" proposition: innovation can influence competitiveness, but it is highly unlikely that the change of competitiveness (no matter how we measure it) could influence innovation since enterprises make their decisions to invest, modernize or spend more on innovation regarding on their own considerations of the market, product, technology, etc., but not on the performance of a region they are located in.

The general model of competitiveness quotient dependence on innovation development parameters can be described as follows:

$$
C Q=f\left(X 1 ; X_{2} ; \ldots X_{n}\right) \text {, }
$$

where $\mathrm{X} 1 ; \mathrm{X} 2 ; \ldots \mathrm{Xn}$ - parameters of regional innovation development.

Regional innovation development parameters are taken formally to fit the data availability constraints. We took the following three indicators, denoted by the Russian Statistics Authority, as the key ones: number of advanced technologies in use, technological innovation expenditure, and investment in fixed assets.

The linear type of a model, in contrast to the non-linear model, was chosen due to the data time series characteristics (a linear trend is rather obvious) and the linearity assumption that follows the forecast of the Russian economy moderate growth in terms of GDP and global competitiveness.

\section{Results and Discussion}

The modelling results prove the initial hypothesis: regions' competitiveness responds to innovation change in different manners. Investment in fixed assets is found to be the most significant influencer in the three clusters (Cluster 1, 2 and 5). Cluster 1 is the only group of regions that, on average, benefits from the advanced technologies use intensification and expansion, while all the other clusters have negative values of the respective regression coefficient. Compared to the "current leaders", the "potential leaders" are still far from the performance boost dilution effect but spending more on technology will undermine the total competitiveness surplus. It means that the regions from the groups with traditional competitiveness factors and moderate and leading competitiveness have not reached the stage yet when "quantity transforms into quality", i.e. their production systems are not able to become more efficient through the increase in the number of used technologies (Table 4).

Our conclusion regarding Cluster 2 to denote it as a "traditional factor employer" was confirmed: the massive technological change is costly, that is why the number of technologies in use should not grow. The expenditure to support one or two modern technologies in traditional sectors will be combined with the capital investment expansion in the favor of "the known" technological mode support. The production systems of the regions with traditional competitiveness factors have an insignificant dependence on the number of innovations. These regions are inert, which largely clarifies the wave nature of their competitiveness quotient that 
changes according to the transformation of the Russian economy competitiveness being "tied" to it. In addition, it is obvious that the regions with leading values and innovation outperformance have the best opportunities to fund these innovations, to create a significant backup, and to postpone the impact from the innovation development.

General description of the degree of impacts

Table 4 from the studied factors on integrated regional competitiveness

\begin{tabular}{|l|c|c|c|c|}
\hline \multirow{2}{*}{ Cluster } & \multicolumn{4}{|c|}{$\begin{array}{c}\text { Factor's name and impact degree } \\
\text { (in relevant scale) }\end{array}$} \\
\cline { 2 - 5 } & $\begin{array}{c}\text { Number of } \\
\text { advanced } \\
\text { technologies in use }\end{array}$ & $\begin{array}{c}\text { Technological } \\
\text { innovation } \\
\text { expenditure }\end{array}$ & $\begin{array}{c}\text { Investment in } \\
\text { fixed assets }\end{array}$ & $\begin{array}{c}\text { Other } \\
\text { factors }\end{array}$ \\
\hline 1. Potential competitiveness & 5.08 & -4.05 & 9.33 & -20.77 \\
leaders & $(0.39)$ & $(-0.54)$ & $(0.91)$ & $(-1.55)$ \\
\hline 2. Traditional competitiveness & -0.27 & 2.14 & 5.58 & -9.41 \\
factor employers & $(-0.044)$ & $(0.131)$ & $(0.415)$ & $(-0.689)$ \\
\hline 4. Moderate competitiveness & -1.11 & 0.30 & -0.32 & -10.64 \\
& $(-0.15)$ & $(0.03)$ & $(-0.025)$ & $(-0.84)$ \\
\hline 5. Competitiveness leaders & -14.51 & 29.19 & 22.71 & -103.40 \\
& $(-0.74)$ & $(1.66)$ & $(1.78)$ & $(-8.3)$ \\
\hline
\end{tabular}

The indicator "technological innovation expenditure" demonstrates the opposite situation: it has a negative impact on regional competitiveness in the first cluster, but it positively influences the other regions. In fact, it means that there are competitive production systems in the "potential competitiveness leader" regions, and there is no need for a dynamic increase in the number of advanced technologies through additional technological innovation expenditure. In terms of quantity, it means that a decrease in technological innovation costs by $1 \mathrm{~m}$ rubles in the first cluster regions can lead to an increase of the integrated competitiveness indicator by 0.54 , all other things being equal. By increasing technological innovation costs by $1 \mathrm{~m}$ rubles, "competitiveness leaders" could improve the competitiveness index by 1.66 , excluding the impacts from counterfactors.

The intercept in a regression equation should be considered as well. It reflects (with certain conditionality) the influence on the regional competitiveness quotient of factors and random processes that are not included in the model. In all cases, the intercept is negative. Considering the dimensionality of this parameter, we can claim that the sensitivity to "other factors" is the lowest among the regions with traditional factors and moderate competitiveness. In other words, factors included in the model have the least impact on the studied phenomenon among all models, and all other factors do not ensure the translation movement. By contrast, leaders and potential leaders demonstrate "manageable competitiveness" when the instruments and mechanisms of influence on innovation development to change regional competitiveness can be applied.

Possible verification can be derived from the European cases indicating that regional competitiveness is presumed to be enhanced by entrepreneurship development, raising FDI, and by the territorial concentration of R\&D centers, but in fact is the most significantly influenced by the GDP per capita, the employment rate and the labor productivity (Török 2017). Lower levels of regional competitiveness are attributed to regions with more labor intensive output, while regions with a higher level of education, innovation and productivity enjoy their greater contribution to the regional economy's growth (Romão and Nijkamp 2017). 


\section{Conclusions}

The problem of pluralism in identifying categories of regional competitiveness can be solved not through theories but through management practice, especially at strategic level. There are reasons to suppose that the approach that is promoted by many researchers and it is based on the "removal" of competitiveness from a set of relatively interrelated indicators of socioeconomic system development is incorrect because the competitiveness characteristic does not determine the phenomenon on its own. That is why the phenomenon should be considered as an attribute to the regional strategic management construction: slogan-like formal strategies that are implemented in the multitude of the Russian regions require significant revision. If we want to manage competitiveness, a proper performance indicator is needed. The one we propose in this paper can be instrumental.

The interrelation between the level of competitiveness and the parameters of regional innovation development was estimated and proved plausible. The insights about the nature and strength of such interrelations will allow the justification of the selected use of competitiveness management instruments, depending on the regions types and based on the parameters of competitive specialization, the efficiency of regional production systems, the levels of innovation activity and the innovation development parameters.

The further research pathway is to seek the ways to integrate competitiveness into strategic management mechanisms not at the level of the aims and objectives but at the level of the fundamental philosophy of "total competitiveness management", akin to the well-known "total quality management".

Greater concern is represented by the innovation policy and strategy adjustments designed to enhance competitiveness. We prove that the uniform rule of technological modernization and innovation technology implementation is going to cause different outcomes in terms of overall competitiveness, regional performance or value creation. The latter is discussed in our forthcoming papers: we suggest the regional free cash-flow indicator (Kolmakov and Polyakova 2019) to be used for measuring the regional performance response to different triggers including innovation pattern changes. The two surveys results' combination will contribute to the more precise model specification that would consider "innovation triggers" allowing to get initial estimates for response surface tests' parametrization and will enable other computational approaches to get more specific outcomes.

\section{Acknowledgements}

This article is part of the research: "Financial and economic aspects of the sharing economy influence on business value", financed by a grant from the Plekhanov Russian University of Economics. We thank the anonymous reviewers for their valuable advice and suggestions that assisted in improving the manuscript.

\section{References}

ALEXA D., CISMAS L. M., RUS A. V., POP SILAGHI M. I. (2019), Economic growth, competitiveness and convergence in the European regions. A spatial model estimation, Economic Computation and Economic Cybernetics Studies and Research 53 (1), 107-124.

CHAYNIKOVA L. N. (2010), Growth of innovative capacity of a region as a reserve for regional competitiveness increase, Bulletin of the Chuvash University 2, 487-491.

FUNDEANU D. D., BADELE C. S. (2014), The impact of regional innovative clusters on competitiveness, Procedia - Social and Behavioral Sciences 124, 405-414. 
GAVUROVA B., SOLTES M., KOVAC V. (2017), Application of cluster analysis in process of competitiveness modelling of Slovak Republic regions, Transformations in Business \& Economics 16 (3), 129-147.

GOLOVIKHIN S. A., NEZHIVENKO E. A. (2012), Theoretical approaches to regional economy research based on the concept of regional competitiveness, Modern Problems of Science and Education 5, 246-256.

HUGGINS R., IZUSHI H., PROKOP D., THOMPSON P. (2016), The global competitiveness of regions, Routledge, London.

HUGGINS R., LUO S., THOMPSON P. (2014), The competitiveness of China's leading regions: Benchmarking their knowledge-based economies, Journal of Economic and Social Geography 105 (3), 241-267.

HUGGINS R., THOMPSON P. (2017), Handbook of regions and competitiveness: Contemporary theories and perspectives on economic development, Elgar Publishing, London.

KOLMAKOV V., EKIMOVA K., ORDOV K., ALIEV A., TCHUYKOVA N. (2018), Monetary policy influence on companies' competitiveness through credit channel, European Research Studies Journal 21 (2), 614-623.

KOLMAKOV V., POLYAKOVA A. (2019), Regional free cash flow dataset: An approach to regional performance evaluation, Data in Brief 25, 104175.

KOLMAKOV V., POLYAKOVA A., KARPOVA S., GOLOVINA A. (2019), Cluster Development Based on Competitive Specialization of Regions, Economy of Region 15 (1), 270284.

KOVALSKA L. (2013), Methodical approaches to analysis and estimation of region's competitiveness, Actual Problems of Economics 141 (3), 109-124.

KRUEGER R., GIBBS D., CARR C. (2018), Examining regional competitiveness and the pressures of rapid growth: An interpretive institutionalist account of policy responses in three city regions, Environment and Planning C: Politics and Space 36 (6), 965-986.

PESSOA A. (2013), Competitiveness, clusters and policy at the regional level: Rhetoric vs. practice in designing policy for depressed regions, Regional Science Inquiry Journal 5 (1), 101-116.

POLYAKOVA A. G., LOGINOV M. P., SEREBRENNIKOVA A. I., THALASSINOS E. I. (2019), Design of a socio-economic processes monitoring system based on network analysis and big data, International Journal of Economics and Business Administration 7 (1), 130-139.

PORTER M. E. (1998), Clusters and the new economics of competition, Harvard Business Review 76 (6), 77-90. 549-578.

PORTER M. (2003), The economic performance of regions, Regional Studies 37 (6-7),

PROKOP V., STEJSKAL J. (2015), Impacts of local planning to competitiveness index change - using approximate initial analysis of the Czech regions, WSEAS Transactions on Business and Economics 12, 279-288.

RATTEN V. (2018), Eco-innovation and competitiveness in the Barossa Valley wine region, Competitiveness Review 28 (3), 318-331.

ROMÃO J., NIJKAMP P. (2017), Impacts of innovation, productivity and specialization on tourism competitiveness - a spatial econometric analysis on European regions, Current Issues in Tourism 22 (10), 1150-1169.

ROSSU E., DONA I. (2016), Measuring the regional and local competitiveness. Case study: South-East region and Braila county, Scientific Papers. Series "Management, Economic Engineering in Agriculture and Rural Development" 16 (1), 445-450.

TIGUINT B., HOSSARI H. (2018), Research and development, innovation and SME competitiveness: Evidence from manufacturing enterprises in Marrakesh region, Morocco, Asia Life Sciences 1, 155-169.

TÖRÖK I. (2017), Competitiveness of Romanian regions in the spatial structure of the EU, IOP Conference Series: Earth and Environmental Science 95, 052013.

YAN X., YAN L., YAO X.-L., LIAO M. (2015), The marine industrial competitiveness of 
blue economic regions in China, Marine Policy 62, 153-160.

ZHAI R.-X., ZHANG Y. (2012), Evaluation of marine economic comprehensive competitiveness in coastal regions based on factor analysis, 2012 Fourth International Conference on Computational and Information Sciences, 1339-1342.

ŽíTEK V., KLÍMOVÁ V. (2015), The competitiveness index of Czech regions, Acta Universitatis Agriculturae et Silviculturae Mendelianae Brunensis 63 (2), 693-701.

Initial submission: 16.04.2019

Revised submission: 03.10.2019

Final acceptance: 03.12.2019

Correspondence: Plekhanov Russian University of Economics, Stremyanny lane 36, 117997, Moscow, Russia.

Email: agpolyakova@mail.ru 